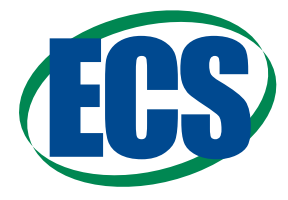

\title{
The Key to High Performance Low Pt Loaded Electrodes
}

\author{
A. Orfanidi, ${ }^{a,=, *, z}$ P. Madkikar, ${ }^{a,=, *}$ H. A. El-Sayed, ${ }^{\text {a }}$ G. S. Harzer, ${ }^{a, *}$ T. Kratky, ${ }^{b}$ \\ and H. A. Gasteiger ${ }^{\mathrm{a}, * *}$ \\ ${ }^{a}$ Chair of Technical Electrochemistry, Department of Chemistry and Catalysis Research Center, Technische Universität \\ München, D-85748 Garching, Germany \\ ${ }^{b}$ Chair of Physical Chemisty with Focus on Catalysis, Department of Chemistry and Catalysis Research Center, \\ Technische Universität München, D-85748 Garching, Germany
}

\begin{abstract}
The effect of ionomer distribution on the oxygen mass transport resistance, the proton resistivity of the cathode catalyst layer, and the $\mathrm{H}_{2}$ /air fuel cell performance was investigated for catalysts with surface modified carbon supports. By introducing nitrogen containing surface groups, it was shown that the ionomer distribution in the cathodic electrode can be optimized to decrease mass transport related voltage losses at high current density. The in house prepared catalysts were fully characterized by TEM, TGA, elemental analysis, and XPS. Thin-film rotating disk electrode measurements showed that the carbon support modification did not affect the oxygen reduction activity of the catalysts, but exclusively affects the ionomer distribution in the electrode during electrode preparation. Limiting current measurements were used to determine the pressure independent oxygen transport resistance - primarily attributed to oxygen transport in the ionomer film - which decreases for catalysts with surface modified carbon support. Systematically lowering the ionomer to carbon ratio (I/C) from 0.65 to 0.25 revealed a maximum performance at $\mathrm{I} / \mathrm{C}=0.4$, where an optimum between ionomer thickness and proton conductivity within the catalyst layer is obtained. From this work, it can be concluded that not only ionomer film thickness, but more importantly ionomer distribution is the key to high performance low $\mathrm{Pt}$ loaded electrodes.

(C) The Author(s) 2017. Published by ECS. This is an open access article distributed under the terms of the Creative Commons Attribution 4.0 License (CC BY, http://creativecommons.org/licenses/by/4.0/), which permits unrestricted reuse of the work in any medium, provided the original work is properly cited. [DOI: 10.1149/2.1621704jes] All rights reserved.

(cc) BY
\end{abstract}

Manuscript submitted November 28, 2016; revised manuscript received February 17, 2017. Published March 2, 2017.

Since 2015, proton exchange membrane fuel cell (PEMFC) electric vehicles (FCEVs) are emerging in the market. Despite the major breakthroughs in achieving the durability and performance targets for automotive applications, the cost of fuel cell stacks is still higher compared to the competing internal combustion engines, which is partly related to the cost and supply constraints of the platinum based catalysts, especially for the air cathode (the fast kinetics of the hydrogen oxidation reaction allow for low anode Pt loadings without compromising performance ${ }^{1}$ ). For large-scale commercial viability, it has been estimated that the Pt loading, especially at the cathode needs to be reduced below $0.1 \mathrm{mg}_{\mathrm{Pt}} / \mathrm{cm}_{\text {geo. }}^{2}{ }^{2,3}$

Over the past decade there have been numerous studies focusing on the optimization of the catalyst layer and seeking to gain fundamental insights into the various kinetic and transport resistances, which limit the performance of air cathodes, particularly at low Pt loadings. ${ }^{4-8}$ While several methods were developed to quantify the voltage losses, there still remain unexplained voltage losses at high current density, particularly in the case of low Pt loading cathodes. ${ }^{9-14}$ These have been rationalized by suggesting more complex oxygen reduction reaction (ORR) kinetics with variable Tafel slope ${ }^{4}$ by an interfacial resistance at the ionomer/platinum interface, ${ }^{9,15}$ and/or by unusually high oxygen transport resistances through an assumed homogeneous thin ionomer film covering the Pt particles. ${ }^{16,17}$ However, recent high-resolution transmission electron microscopy studies suggested that the ionomer coverage in the electrode may be rather inhomogeneous ${ }^{18}$ and that the solvents used for preparing catalyst inks for electrode preparation influence the ionomer distribution in the final electrode, which in turn affects MEA (membrane electrode assembly) performance. ${ }^{19}$ Therefore, one of the challenges in preparing MEAs is to achieve catalyst layers with a homogeneous ionomer distribution. This is not only expected to lead to maximum MEA performance, but also to allow for a more quantitative assignment of the transport related voltage losses, as all transport resistance measurements and voltage loss corrections are based on assuming uniform ionomer distribution in the electrode.

In the following, we will show that a modification of the carbon support of the platinum catalyst and an optimization of the ionomer

\footnotetext{
$=$ These authors contributed equally to this work.

*Electrochemical Society Student Member.

**Electrochemical Society Fellow.

${ }^{\mathrm{z} E}$-mail: alin.orfanidi@tum.de
}

content of the cathode catalyst layer result in a significant improvement of the MEA performance with ultra-low Pt loadings (ca. 0.07 $\mathrm{mg}_{\mathrm{Pt}} / \mathrm{cm}^{2}$ ). We hypothesize that this is due to achieving a more homogeneous ionomer coverage on the carbon support (Vulcan XC72) which we functionalized with amide/imide/lactam groups $\left(-\mathrm{NH}_{\mathrm{x}}\right)$, which are known to ionically interact with the ionomer's sulfonic acid groups $\left(-\mathrm{SO}_{3} \mathrm{H}\right){ }^{20,21}$ This hypothesis is consistent with a very recent conference report ${ }^{22}$ and with our finding that the unassigned MEA voltage losses, i.e., after correction for the measured proton and oxygen transport resistances, are reduced to unprecedentedly low values in MEAs based on $\mathrm{NH}_{\mathrm{x}}$-functionalized carbon supports.

\section{Experimental}

Carbon functionalization with $\mathrm{NH}_{x}$ surface groups. $-2 \mathrm{~g}$ of commercially available Vulcan XC72 (Tanaka Kikinzoku Kogyo K.K.) was mixed with $100 \mathrm{ml}$ of $70 \% \mathrm{HNO}_{3}$ (Sigma Aldrich, ACS reagent) and then immersed into a pre-heated oil bath $\left(70^{\circ} \mathrm{C}\right.$, reflux conditions $)$ for $30 \mathrm{~min}$. The carbon (further on referred to as "V-Ox") was filtrated and washed with hot water until neutral filtrate $\mathrm{pH}$; then it was dried in a vacuum oven for $12 \mathrm{~h}$ at $80^{\circ} \mathrm{C}$. Thereafter, $1 \mathrm{~g}$ of the sample was placed in a tube furnace (Carbolite Gero $\mathrm{GmbH} \& \mathrm{Co} \mathrm{KG}$, Germany) for $4 \mathrm{~h}$ at $200^{\circ} \mathrm{C}$ under pure $\mathrm{NH}_{3}$ gas with a flow rate of $1 \mathrm{l} / \mathrm{min}$ to prepare aminated Vulcan carbon (further on referred to as "V- $\mathrm{NH}_{\mathrm{x}}$ "). This procedure closely follows that described by Jansen et al. ${ }^{23}$

Synthesis of ca. $20 w t \% ~ P t / V-N H_{x} .-300 \mathrm{mg}$ of the aminated Vulcan support, $200 \mathrm{ml}$ of ethylene glycol, $100 \mathrm{ml}$ of deionized water, and $1.54 \mathrm{ml}$ of $\mathrm{H}_{2} \mathrm{PtCl}_{6}\left(8 \mathrm{wt} \% \mathrm{H}_{2} \mathrm{PtCl}_{6}\right.$ in $\mathrm{H}_{2} \mathrm{O}$ (三 $0.25 \mathrm{~mol} / \mathrm{l}$ ) from Alfa Aesar) were placed in a round-bottom flask and stirred for $18 \mathrm{~h}$ at $25^{\circ} \mathrm{C}$. Thereafter, the flask was immersed in a pre-heated oil bath at $120^{\circ} \mathrm{C}$ and stirred for $2 \mathrm{~h}$. The catalyst was separated by filtration and washed with hot water until the filtrate was $\mathrm{pH}$ neutral and chloride free; subsequently, the catalyst was dried in a vacuum oven at $70^{\circ} \mathrm{C}$ for $12 \mathrm{~h} .{ }^{24}$ The final platinum loading was quantified by both TGA and elemental analysis.

Microstructure of carbon.-The surface areas of the commercial and aminated Vulcan carbon were evaluated by $\mathrm{N}_{2}$ physisorption at $77 \mathrm{~K}$ using a Autosorb-iQ instrument (Quantachrome, UK). All samples were degassed under vacuum at $90^{\circ} \mathrm{C}$ for $15 \mathrm{~h}$ prior to physisorption measurements. Adsorption and desorption isotherms of all sam- 
ples were recorded in the relative pressure range of $10^{-5} \leq\left(p / p_{o}\right)$ $\leq 0.995$, where $p$ represents the gas pressure and $p_{o}$ the saturation pressure. This specific relative pressure range was chosen in order to ensure high resolution in the micro and mesopore region; to ensure high accuracy, the sample weight was adjusted to have a minimum absolute surface area of $>10 \mathrm{~m}^{2}$. The specific surface area and pore volume distribution were calculated by the Brunauer-Emmett-Teller (BET) method and by the quenched solid density functional theory (QSDFT) method, respectively (using the ASiQwin program). The adsorption branch was used for the BET surface area (best fit within 0.01 $\left.\leq\left(p / p_{o}\right) \leq 0.25\right)$ using a multipoint fit. In addition, a slit/cylindrical pore and adsorption QSDFT kernel was used for the characterization of the nanopore size distribution (small mesopores and micropores with $<30 \mathrm{~nm}$ ) of the carbons. It should be noted that QSDFT is more accurate than other theories or non-local density functional theory (NLDFT), as it takes into consideration the heterogeneity of the carbon surface and thus gives a more realistic estimate of the micro and mesopores contribution. ${ }^{25,26}$

Transmission electron microscopy.-Transmission electron microscopy (TEM) was used to evaluate the Pt distribution on the carbon support. Samples for TEM analysis were prepared by dispersing a very small amount of the catalyst in deionized water and then depositing a few drops of the suspension onto carbon-coated $\mathrm{Cu} 400$ TEM grids (Science Services, Germany). Imaging was performed using a CM100 EM (Philips, Netherlands) operated at $100 \mathrm{kV}$ and a resolution of 0.5 $\mathrm{nm}$. For the evaluation of the average Pt particle size distribution, 230 individual particles were measured manually using ImageJ.

Thermogravimetric analysis.-Thermogravimetric analysis (TGA) of the carbons (V, V-Ox, and $\mathrm{V}-\mathrm{NH}_{\mathrm{x}}$; all without platinum) was performed with a TGA/DSC 1 (Mettler Toledo, Switzerland) in pure argon at $5 \mathrm{~K} / \mathrm{min}$ in order to quantify the amount of functional groups on the pristine, oxidized, and aminated carbons. The $\mathrm{Pt}$ content was also evaluated by TGA from the residual sample weight after burning the carbon by heating the sample to $1000^{\circ} \mathrm{C}$ under $83 \%$ $\mathrm{O}_{2}$ in $\mathrm{Ar}$ atmosphere.

While the nominal Pt loadings for the here prepared catalyst (supported on $\mathrm{V}-\mathrm{NH}_{\mathrm{x}}$ ) and the commercial catalyst (supported on $\mathrm{V}$ ) is $20.0 \mathrm{wt} \%$, it is critical for this study to precisely quantify the Pt loadings, which we have done by TGA. The thus determined Pt content of the here prepared $\mathrm{Pt} / \mathrm{V}-\mathrm{NH}_{\mathrm{x}}$ catalyst was $20.3 \mathrm{wt} \%$ and that of the commercial $\mathrm{Pt} / \mathrm{V}$ catalyst was $19.4 \mathrm{wt} \%$ (which was in perfect agreement with the value provided by the manufacturing company, 19.6 wt \%). For this study we used for the commercial Pt/V the Pt loading provided by the manufacturing company.

Elemental analysis.-CHNS analyses were done using a EURO EA analyzer (Hekatech, Germany), which is based on the dynamic flash combustion technique. The Pt content was analyzed photometrically using a UV 160 photometer (Shimadzu, Japan).

$X$-ray photoelectron spectroscopy.-Surface chemical analysis was accomplished by X-ray photoelectron spectroscopy (Leybold-Heraeus LHS 10 XPS with a non-monochromatized Mg $\mathrm{K} \alpha$ source). The powder samples were pressed and fixed onto a vacuum compatible copper foil adhesive tape. The spectra were recorded at a constant pass energy of $100 \mathrm{eV}$, corresponding to an energy resolution of $\sim 1.1 \mathrm{eV}$. The measured $\mathrm{C} 1 \mathrm{~s}$ peak at a binding energy of $284.5 \mathrm{eV}$ indicates the absence of sample charging. All spectra were recorded at a pressure below $5 \cdot 10^{-8}$ mbar. The core level spectra were fitted by Voigt functions after subtraction of a linear background.

Rotating disk electrode.-Electrochemical characterization of the catalysts was done by the thin-film rotating disk electrode (RDE) technique, comparing the intrinsic activities of commercial Vulcan XC72 supported platinum catalyst (19.6 wt\% Pt/V from TKK) with that of the here synthesized $\mathrm{Pt} / \mathrm{V}-\mathrm{NH}_{\mathrm{x}}$ catalyst $(20.3 \mathrm{wt} \% \mathrm{Pt})$. The catalyst inks were prepared by mixing $7.8 \mathrm{mg}$ of $\mathrm{Pt} / \mathrm{V}$ in $5.57 \mathrm{ml}$ of
$\mathrm{DMF}$ and $7.0 \mathrm{mg}$ of $\mathrm{Pt} / \mathrm{V}-\mathrm{NH}_{\mathrm{x}}$ in $5.0 \mathrm{ml}$ of $\mathrm{DMF}$ (both equating to $1.4 \mathrm{mg}_{\text {catalyst }} / \mathrm{ml}$ ). Ink suspensions were bath-sonicated for $15 \mathrm{~min}$. No Nafion was added to the inks in order to ascertain the true mass and specific activities of catalysts without any poisoning caused by Nafion. ${ }^{27} 5 \mu \mathrm{l}$ of the ink was drop-cast onto a polished $(0.05 \mu \mathrm{m}$ alumina, Bühler, Germany) and pre-cleaned stationary $5 \mathrm{~mm}$ diameter GC electrode (Pine, USA), resulting in a catalyst loading of 36 $\mu \mathrm{g} / \mathrm{cm}^{2}$. The electrode was covered with a beaker and the catalyst film was dried overnight at room temperature in order to yield a homogeneous film. All electrochemical measurements were conducted in a home-made three-electrode jacketed glass cell. The electrode was attached to a rotator (Pine, USA), which was connected to a potentiostat (Autolab, Germany). A reversible hydrogen electrode (RHE) was used as a reference electrode, which was calibrated at the beginning of each experiment. All measurements were done at $25^{\circ} \mathrm{C}$ in $0.1 \mathrm{M} \mathrm{HClO}_{4}$ which was prepared from $18 \mathrm{M} \Omega \cdot \mathrm{cm}$ Milli-Q water (Merck Millipore, Germany) and $\mathrm{HClO}_{4}(60 \%$, analytical grade, Kanto Chemical, Japan). All gases ( $\mathrm{Ar}, \mathrm{O}_{2}$, and $\mathrm{H}_{2}$ ) were of 6.0 grade (Westfalen, Germany). The reported potentials are referenced to the RHE scale and are iR-free. ORR activities were extracted at $1600 \mathrm{rpm}$ from $20 \mathrm{mV} / \mathrm{s}$ anodic scans. Mass and specific activities are extracted after applying the mass transport correction for RDE. ${ }^{28}$

Membrane electrode assembly preparation.-All $5 \mathrm{~cm}_{\text {geo }}^{2}$ membrane electrode assemblies (MEAs) were fabricated using the decal transfer method. Catalyst inks were prepared by mixing the catalyst with a low-EW ionomer containing water-solvent dispersion (Asahi Kasei, Japan, $\left.700 \mathrm{EW}\left(\mathrm{EW} \equiv g_{\text {polymer }} / \mathrm{mol}_{\mathrm{H}+}\right)\right)$. The ink components were added into a $8 \mathrm{ml}$ HDPE capped bottle containing $16.5 \mathrm{~g}$ of $5 \mathrm{~mm}$ $\mathrm{ZrO}_{2}$ beads in the following sequence: catalyst, water, 1-propanol, and finally the ionomer dispersion. The water concentration in the inks was $10 \mathrm{wt} \%$, while the solid content was $0.03 \mathrm{~g} / \mathrm{ml}_{\text {ink }}$ in order to obtain a suitable viscosity for the coating process. Three ionomer to carbon weight ratios (I/C) were used: $0.65,0.40$, and 0.25 . The inks were mixed by placing the bottles onto a roller-mill $(60 \mathrm{rpm})$ for $18 \mathrm{~h}$ at room temperature. Thereafter, the inks were coated onto virgin PTFE using a mayer rod coater.

The noble metal loading of the cathode electrodes was ca. 0.07 $\mathrm{mg}_{\mathrm{Pt}} / \mathrm{cm}^{2}$ geo (see details in Table III) for all cases. The loading of the electrodes was determined by weighting the decals before and after the catalyst layer transfer. The same anodes were used for all measurements: $0.1 \mathrm{mg}_{\mathrm{Pt}} / \mathrm{cm}^{2}{ }_{\text {geo }}$ consisting of $19.6 \mathrm{wt} \% \mathrm{Pt} / \mathrm{V}(\mathrm{TKK})$ with an $\mathrm{I} / \mathrm{C}$ ratio of 0.65 . The MEAs were assembled by hot pressing a 15 $\mu \mathrm{m}$ membrane (Asahi Kasei) placed between the anode and cathode decals at $155^{\circ} \mathrm{C}$ for $3 \mathrm{~min}$ with an applied force of $0.11 \mathrm{kN} / \mathrm{cm}^{2}$. All inks and decals were manufactured twice to verify reproducibility. For each MEA type, two independent fuel cell measurements were conducted; the average value of the measurements with error bars corresponding to the standard deviation are depicted in all figures.

Fuel cell operation.-The electrochemical measurements were performed using a single-cell hardware purchased from Fuel Cell Technologies Inc., fitted with $5 \mathrm{~cm}^{2}$ geo active area graphite flowfields $^{29}$ ( $0.5 \mathrm{~mm}$ lands/channels; made by Poco Graphite). The assembling torque applied was $12 \mathrm{Nm}$ and the compression of the gas diffusion media (Freudenberg H14C7) was set to $20 \%$ by using incompressible fiber-glass PTFE sub-gaskets.

Fuel cell tests were performed on an automated Greenlight Innovation fuel cell test station (type G60). All MEAs were conditioned before each test using the same voltage-controlled ramp-in procedure $\left(\mathrm{H}_{2}\right.$ /air flows of $1390 / 3320 \mathrm{nccm}$ at $80^{\circ} \mathrm{C}, 100 \%$ relative humidity, and $150 \mathrm{kPa}_{\text {abs,inlet }}$ ): $0.6 \mathrm{~V}$ for $45 \mathrm{~min}, 5 \mathrm{~min}$ at $\mathrm{OCV}$, and $10 \mathrm{~min}$ at $0.85 \mathrm{~V}$. This sequence was repeated 10 times, after which constant performance was reached. Differential-flow polarization curves were recorded in current-control mode at $80^{\circ} \mathrm{C}, 170 \mathrm{kPa}_{\text {abs }}$ inlet controlled pressure, $100 \%$ relative humidity $(\mathrm{RH})$ for both reactants, and constant flows of $2000 \mathrm{nccm}$ of $\mathrm{H}_{2}$ and $5000 \mathrm{nccm}$ of air or $\mathrm{O}_{2}$ (at these conditions, the inlet to outlet pressure drop in anode and cathode are 2 and $22 \mathrm{kPa}$, respectively). Prior to recording a polarization curve from 
low to high current densities, MEAs were conditioned at $0.75 \mathrm{~V}$ for $15 \mathrm{~min}$; each current density point was held for $10 \mathrm{~min}$. and the resulting voltage was averaged over the final $30 \mathrm{~s}$. AC impedance spectra were collected at each current density to determine the respective high frequency resistance (Gamry Ref3000 potentiostat).

Fuel cell diagnostic measurements.-The electrochemically active surface area (ECSA) of the cathode electrode was evaluated via cyclic voltammetry, averaging the $\mathrm{H}$-desorption and $\mathrm{H}$ adsorption charge and using a reference value of $210 \mu \mathrm{C} / \mathrm{cm}_{\mathrm{Pt}}{ }^{2}$. The counter/reference electrode was fed with $200 \mathrm{nccm}$ of fully humidified $5 \% \mathrm{H}_{2}$ in nitrogen, while the working electrode was first flushed with dry $\mathrm{N}_{2}$, the flow of which was stopped during recording the CVs. The potential was cycled at $150 \mathrm{mV} / \mathrm{s}$ between 0.03 and $1.0 \mathrm{~V}$ (vs. RHE) at $40^{\circ} \mathrm{C}$ and ambient pressure. The shorting resistance and the $\mathrm{H}_{2}$ cross-over currents were measured with $\mathrm{H}_{2} / \mathrm{N}_{2}$ at $170 \mathrm{kPa}_{\text {abs,inlet }}$, $80^{\circ} \mathrm{C}$, and $100 \% \mathrm{RH}$.

The proton conduction resistance in the cathode electrode was determined by AC impedance (Gamry Ref3000 potentiostat) under $\mathrm{H}_{2} / \mathrm{N}_{2}$ (anode/cathode) at $0.2 \mathrm{~V}$, following previous work ${ }^{43}$ (peak-topeak perturbation of $3.5 \mathrm{mV}$ between $500 \mathrm{kHz}$ and $0.2 \mathrm{~Hz}$, with 20 points per decade). Three spectra were collected at each condition to verify reproducibility. Proton conduction resistances $\left(\mathrm{R}_{\mathrm{H}+\text {,cath }}\right)$ were determined at $100,70,50$, and $30 \% \mathrm{RH}$ at $80^{\circ} \mathrm{C}$ under differential flow conditions $\left(\mathrm{H}_{2} / \mathrm{N}_{2}\right.$ at $\left.1000 / 1000 \mathrm{nccm}\right)$, maintaining constant gas partial pressures (i.e., at cell pressures of 270, 255, 246, and 236 $\mathrm{kPa}_{\mathrm{abs}}$,inlet respectively). Under these operating conditions the pressure drop over the flow field was negligible $\left(<2 \mathrm{kPa}_{\mathrm{abs}}\right)$, which resulted in no change in the RH between the inlet and outlet of the cell.

The effective proton resistance $\mathrm{R}_{\mathrm{H}+\text {,cath }}^{\text {eff }}$ (in units of $\Omega \cdot \mathrm{cm}^{2}$ ) was calculated by using Equation 10 from Liu et al. ${ }^{42}$ and was used to correct for the proton conduction resistance induced voltage loss. The proton resistivity $\rho_{\mathrm{H}+\text {,cath }}$ (in units of $\Omega \cdot \mathrm{cm}$ ) was calculated by dividing the proton resistance $\left(\mathrm{R}_{\mathrm{H}+\text {,cath }}\right)$ by the cathode electrode thickness (calculated from the well-known packing density of Vulcan carbon based electrodes of $\left.28 \mu \mathrm{m} /\left(\mathrm{mg}_{\mathrm{C}} / \mathrm{cm}^{2}\right)^{30}\right)$.

The total mass transport resistance was derived from limiting current measurements $\mathrm{s}^{5,11}$ at $80^{\circ} \mathrm{C}$ cell temperature and at $70 \% \mathrm{RH}$ under differential conditions $\left(2000 \mathrm{nccm}\right.$ of $\mathrm{H}_{2}$ and $5000 \mathrm{nccm}$ of $\mathrm{O}_{2} / \mathrm{N}_{2}$ mixtures). The dry mole fraction of oxygen was altered from 0.5 to $24 \% \mathrm{O}_{2}$ in $\mathrm{N}_{2}$, while the cell potential was set to $0.3,0.15$, 0.1 , and $0.05 \mathrm{~V}$ for $2 \mathrm{~min}$ each. To quantify pressure-independent and pressure-dependent oxygen transport resistances, limiting current measurements were conducted at $170,270,350$, and $500 \mathrm{kPa}_{\text {abs,inlet }}$. Under these experimental conditions there was no significant change of the RH over the whole active area of the MEA. To be more precise, the $\mathrm{RH}$ in the inlet of the cell was set at $70 \%$ for all cases, while the resulting $\mathrm{RH}$ at the outlet was $68 \%, 70 \%, 71 \%$, and $73 \%$ for the $170,270,350$, and $500 \mathrm{kPa}_{\mathrm{abs} \text {,inlet }}$, respectively, based on the measured pressure drop at a given flow rate and pressure as well as a water production corresponding to $4 \mathrm{~A} / \mathrm{cm}^{2}{ }_{\text {geo }}$.

\section{Results}

Carbon and catalyst characterization.-CHNS elemental analysis (see Table I) was conducted in order to determine the functionalization degree of the pristine Vulcan XC72 carbon (V), after its oxidation $(\mathrm{V}-\mathrm{Ox})$, and after its subsequent amination $\left(\mathrm{V}-\mathrm{NH}_{\mathrm{x}}\right)$. It is well known that oxidation of carbon in concentrated $\mathrm{HNO}_{3}$ leads

\section{Table I. Elemental analysis (CHNS) of the different carbon} supports.

\begin{tabular}{ccccc} 
Sample & $\mathrm{C}[\%]$ & $\mathrm{H}[\%]$ & $\mathrm{N}[\%]$ & $\mathrm{S}[\%]$ \\
\hline $\mathrm{V}$ & $98.8 \pm 0.3$ & 0.0 & $0.2 \pm 0.3$ & $0.5 \pm 0.3$ \\
$\mathrm{~V}-\mathrm{Ox}$ & $95.1 \pm 0.3$ & $0.1 \pm 0.3$ & $0.4 \pm 0.3$ & $0.5 \pm 0.3$ \\
$\mathrm{~V}^{-\mathrm{NH}_{\mathrm{x}}}$ & $96.8 \pm 0.3$ & $0.2 \pm 0.0$ & $0.9 \pm 0.0$ & $0.5 \pm 0.0$
\end{tabular}

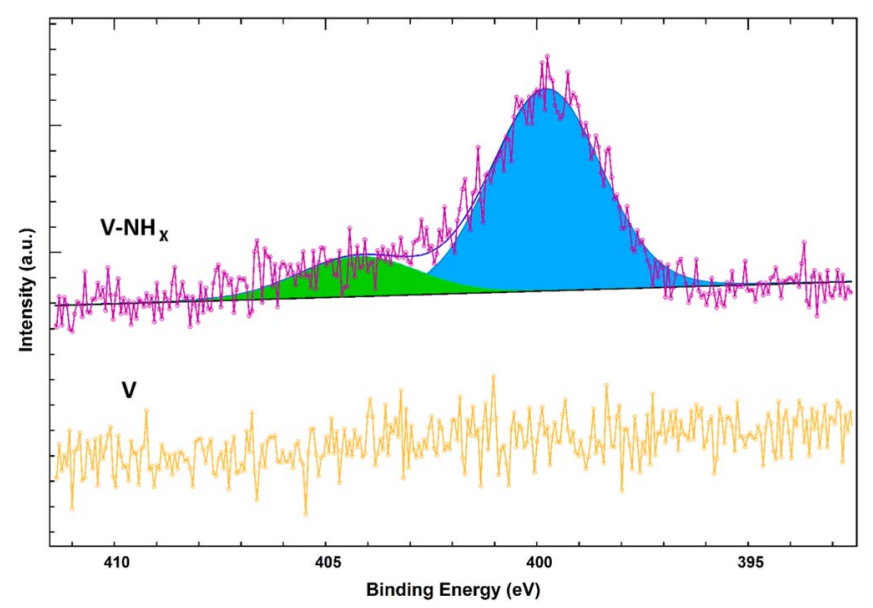

Figure 1. $\mathrm{XP}$ spectra of $\mathrm{V}$ and $\mathrm{V}-\mathrm{NH}_{\mathrm{X}}$ carbons in the $\mathrm{N}$ 1s region.

to a surface functionalization with carboxylic, hydroxyl, and $\mathrm{NO}_{\mathrm{x}}$ groups. ${ }^{31,32}$ Accordingly, the N-content of the oxidized Vulcan support is significantly higher than that of the pristine carbon (see Table I). It further increases after the heat-treatment in $\mathrm{NH}_{3}$ to $0.9 \%$ (see $\mathrm{V}-\mathrm{NH}_{\mathrm{x}}$ in Table I), owing to the formation of amides/imides/lactams upon reaction with $\mathrm{NH}_{3} \cdot{ }^{23}$ With the increase in $\mathrm{N}$-content, a simultaneous increase in the C-content is also seen (from 95.1 to $96.8 \mathrm{wt} \%$ ), which is due to the loss of less stable $\mathrm{O}$-containing functional groups during heat-treatment. The carbon content determined by CHNS analysis (see Table I) is in excellent agreement with that determined by TGA analysis (see Figure S1).

The presence and nature of the $\mathrm{N}$-containing functional groups on the $\mathrm{V}^{-\mathrm{NH}_{\mathrm{x}}}$ support was examined by X-ray Photoelectron Spectroscopy (XPS). The broad peak at $399.8 \mathrm{eV}$ (see Figure 1) is consistent with the presence of imides/lactams/amides; ${ }^{33}$ while it is not possible by XPS to distinguish between the different groups. ${ }^{34}$ The pristine Vulcan XC72 carbon was also subjected to the same analysis and, as expected, no N-containing surface groups could be detected (Figure 1).

The microstructure of the pristine (V) and functionalized carbon $\left(\mathrm{V}-\mathrm{NH}_{\mathrm{x}}\right)$ was investigated via $\mathrm{N}_{2}$ adsorption isotherm, seeking to determine any potential changes in the microstructure of the support by the amination treatment, as this could affect the performance of the catalyst in low Pt loaded electrodes. ${ }^{35}$ Table II depicts the results from the BET and the QSDFT analysis. The total surface area estimated by BET (first row in Table II) and QSDFT (i.e., the sum of micro and mesopore areas from QSDFT analysis) are in perfect agreement. QSDFT determines the contribution of the micropores and mesopores to the total area (see experimental for more details). Using the IUPAC classification, ${ }^{36}$ the contribution of the micropores $(<2 \mathrm{~nm})$ and the mesopores $(>2 \mathrm{~nm}$ ) to the total surface area was quantified (see Table II and Figure S2). The area of the micropores is commonly referred to as internal surface area, while the one of the mesopores is referred to as external area of a carbon support. Functionalization of the Vulcan carbon with $\mathrm{NH}_{\mathrm{x}}$ groups clearly results in a decrease of the internal porosity of the carbon support (from 127 to $74 \mathrm{~m}^{2} / \mathrm{g}$ ),

Table II. Surface area analysis of pristine Vulcan carbon (V) and aminated carbon $\left(\mathrm{V}-\mathrm{NH}_{\mathrm{x}}\right) .1^{\text {st }}$ row: total surface area determined by BET; $2^{\text {nd }}$ and $3^{\text {rd }}$ row: meso and micropore areas determined by QSDFT.

\begin{tabular}{cccc} 
Carbon & Units & V & V-NH \\
\hline Surface area & $\mathrm{m}^{2} / \mathrm{g}_{\mathrm{C}}$ & 231 & 175 \\
Mesopores & $\mathrm{m}^{2} / \mathrm{g}_{\mathrm{c}}$ & 102 & 101 \\
Micropores & $\mathrm{m}^{2} / \mathrm{g}_{\mathrm{C}}$ & 127 & 74
\end{tabular}



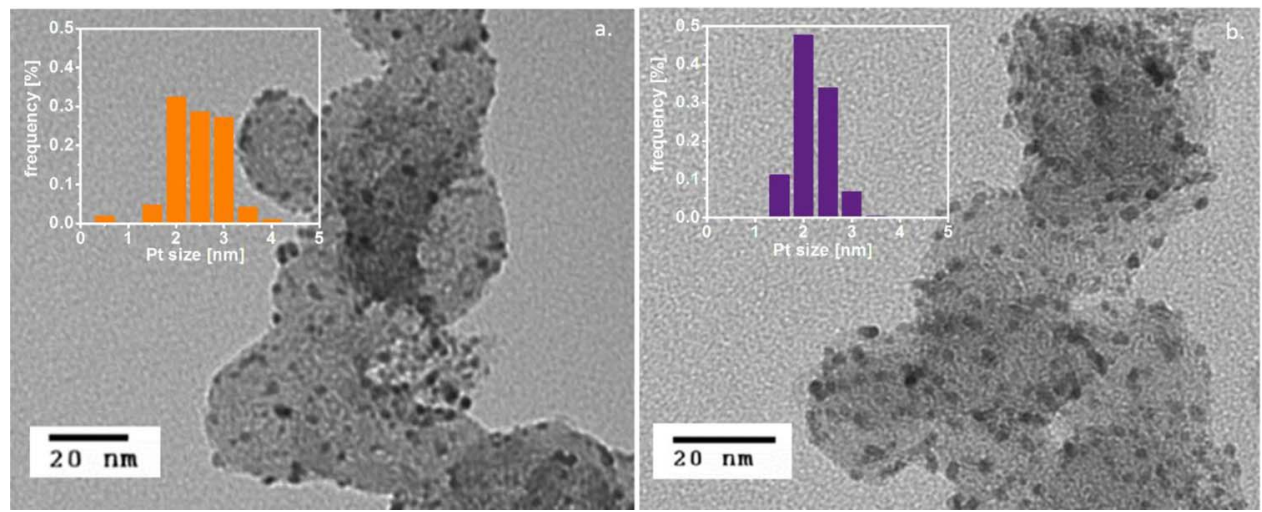

Figure 2. TEM micrographs and their corresponding Pt size distribution for: a. $19.6 \mathrm{wt} \% \mathrm{Pt} / \mathrm{V}$ and b. $20.3 \mathrm{wt} \% \mathrm{Pt} / \mathrm{V}-\mathrm{NH}_{\mathrm{x}}$.

without, however, affecting the external surface area of the carbon and the mesopore size distribution (see Figure S2). The observed decrease in micropore area was previously suggested to be due to the blocking of micropores by functional groups. ${ }^{37}$

TEM micrographs of the commercial $\mathrm{Pt} / \mathrm{V}$ and the here prepared $\mathrm{Pt} / \mathrm{V}-\mathrm{NH}_{\mathrm{x}}$ catalyst were obtained to determine their Pt particle size distribution. Representative micrographs and the corresponding particle size distribution histograms are shown in Figure 2. It is clear that both catalysts exhibit a similar and reasonably narrow Pt distribution over the carbon support (see also Figure S3), as well as similar average Pt particle diameters of $2.4 \pm 0.6 \mathrm{~nm}$ for the $19.6 \mathrm{wt} \% \mathrm{Pt} / \mathrm{V}$ catalyst and of $2.2 \pm 0.4 \mathrm{~nm}$ for the $20.33 \mathrm{wt} \% \mathrm{Pt} / \mathrm{V}-\mathrm{NH}_{\mathrm{x}}$, catalyst (see Table S4).

No changes of the surface functionalization are expected to occur during the Pt deposition procedure used in the present work, as was demonstrated by XPS measurements in an earlier work. ${ }^{24}$

Evaluation of the ORR activity by RDE.-Thin-film RDE ORR activity measurements were performed on the catalysts with functionalized and non-functionalized carbon support. These were done on a Nafion-free thin-film in order to avoid any poisoning of Pt due to Nafion and to exclude any interaction of Nafion with the functionalized catalyst. The obtained mass and specific activities are in good agreement with the literature for Nafion-free films. ${ }^{27}$ Table III shows that the ORR mass activity of the catalyst with the functionalized support $\left(\mathrm{Pt} / \mathrm{V}-\mathrm{NH}_{\mathrm{x}}\right)$ is the same as that of the non-functionalized support (Pt/V), both also displaying the same Tafel slope (see Table III and Figure S5). The specific activity of the $\mathrm{Pt} / \mathrm{V}-\mathrm{NH}_{\mathrm{x}}$ catalyst is slightly higher than that of the $\mathrm{Pt} / \mathrm{V}$ catalyst due to the difference in the ECSA (see Table III). This clearly confirms that both catalysts have essentially identical ORR activity and that the functionalization does not significantly influence the ORR activity. Thus, any of the below shown differences in the MEA performance of $\mathrm{Pt} / \mathrm{V}$ vs. $\mathrm{Pt} / \mathrm{V}-\mathrm{NH}_{\mathrm{x}}$ can be unambiguously attributed to the interaction between the ionomer and the support.

Fuel cell characterization.-All cathode electrodes had similar $\mathrm{Pt}$ loading (68-78 $\mu \mathrm{g}_{\mathrm{Pt}} / \mathrm{cm}^{2}{ }_{\text {geo }}$ ) and their detailed specifications, including their electrochemically active surface area (ECSA) are summa-

Table III. Electrochemically active surface area (ECSA), ORR mass $\left(i_{m}\right)$, and specific $\left(i_{s}\right)$ activity at $0.9 \mathrm{~V}$, and Tafel slope (TS) determined by RDE measurements (from the anodic going scan at $20 \mathrm{mV} / \mathrm{s}$ and $1600 \mathrm{rpm}$ in $\mathrm{O}_{2}$ saturated $0.1 \mathrm{M} \mathrm{HClO}_{4}$ at $25^{\circ} \mathrm{C}$ ). All data are corrected for $\mathrm{iR}$ and oxygen mass transport; the errors represent the standard deviations from 3 independent experiments.

\begin{tabular}{ccccc} 
Catalyst & ECSA $\left[\mathrm{m}^{2} / \mathrm{g}_{\mathrm{Pt}}\right]$ & $\mathrm{i}_{\mathrm{m}}\left[\mathrm{mA} / \mathrm{mg}_{\mathrm{Pt}}\right]$ & $\mathrm{i}_{\mathrm{s}}\left[\mu \mathrm{A} / \mathrm{cm}^{2}{ }_{\mathrm{Pt}}\right]$ & $\mathrm{TS}[\mathrm{mV} / \mathrm{dec}]$. \\
\hline $\mathrm{Pt} / \mathrm{V}$ & $74 \pm 2.4$ & $548 \pm 37$ & $828 \pm 26$ & $56 \pm 3.0$ \\
$\mathrm{Pt} / \mathrm{V}-\mathrm{NH}_{\mathrm{x}}$ & $60 \pm 0.5$ & $614 \pm 36$ & $1036 \pm 65$ & $56 \pm 2.0$
\end{tabular}

rized in Table IV. The ionomer to carbon weight ratio (I/C) was altered in order to highlight the role of the ionomer film thickness on the mass transport resistance, as will be discussed further on. The uncorrected $\mathrm{H}_{2} / \mathrm{O}_{2}$ differential flow performance curves at $80^{\circ} \mathrm{C}, 100 \% \mathrm{RH}$, and $170 \mathrm{kPa}_{\text {abs }}$ inlet pressure as well as the corresponding HFR values are depicted in Figure $3 \mathrm{a}$. Figure $3 \mathrm{~b}$ shows the $\mathrm{H}_{2} / \mathrm{O}_{2}$ performance vs cathode Pt-mass normalized current density (in units of $\mathrm{A} / \mathrm{g}_{\mathrm{Pt}}$ ), corrected for the HFR, the effective cathode proton transport resistance $\left(\mathrm{R}_{\mathrm{H}+\text {,cath }}^{\text {eff }}\right.$; calculated from $\rho_{\mathrm{H}+\text {,cath }}$ in Figure $\left.6 \mathrm{a}\right)$, and the $\mathrm{H}_{2}$ crossover $\left(4 \pm 0.5 \mathrm{~mA} / \mathrm{cm}^{2}{ }_{\text {geo }}\right)$, i.e, an analogous correction which had been applied previously. ${ }^{11}$ For each catalyst, two MEAs were prepared and tested to check for reproducibility, with the error bars corresponding to the standard deviation between those two measurements.

The ORR mass activity values $\left(\mathrm{i}_{\mathrm{m}}\right)$ for the $19.6 \mathrm{wt} \% \mathrm{Pt} / \mathrm{V}$ and 20.3 $\mathrm{wt} \% \mathrm{Pt} / \mathrm{V}-\mathrm{NH}_{\mathrm{x}}$ based cathodes were extracted from Figure $3 \mathrm{~b}$ and are summarized in Table IV. As can be seen, the mass activities of the $\mathrm{Pt} / \mathrm{V}$ and the $\mathrm{Pt} / \mathrm{V}-\mathrm{NH}_{\mathrm{x}}$ catalysts are essentially identical, consistent with the identical mass activities determined by RDE (see Table III). In addition, to facilitate a better comparison with the literature, the here obtained ORR mass activities at a total pressure of $170 \mathrm{kPa}_{\mathrm{abs} \text {,inlet }}$ (i.e., $\mathrm{O}_{2}$ and $\mathrm{H}_{2}$ partial pressures of $123 \mathrm{kPa}_{\mathrm{abs} \text {,inlet }}$ ) were also converted to those ORR mass activities $\left(\mathrm{i}_{\mathrm{m}}{ }^{*}\right)$ which are obtained at a cell pressure of $150 \mathrm{kPa}_{\text {abs.inlet }}$ (i.e., $\mathrm{O}_{2}$ and $\mathrm{H}_{2}$ partial pressures of 103 $\mathrm{kPa}_{\text {abs,inlet }}$ ) using Equation 12 from Ref. 38. The ORR mass activity of all MEAs are in good accordance with literature values reported for $20 \mathrm{wt} \% \mathrm{Pt} / \mathrm{V}^{39}$ and other carbon supported catalysts. ${ }^{40}$ Tafel slopes were determined from Figure $3 \mathrm{~b}$ between 50 and $800 \mathrm{~mA} / \mathrm{cm}^{2}(\sim 850$ and $\sim 12500 \mathrm{~A} / \mathrm{g}_{\mathrm{Pt}}$ in Figure $3 \mathrm{~b}$ ), following the approach by Neyerlin et al., ${ }^{38}$ to only use current densities greater than 10 times the $\mathrm{H}_{2}$ crossover current density and up to below $1 \mathrm{~A} / \mathrm{cm}^{2}$. The Tafel slopes of all electrodes range between 72 and $76 \mathrm{mV} / \mathrm{dec}$. (see Table IV),

Table IV. Cathode electrode $\mathrm{Pt}$ loadings $\left(\mathrm{L}_{\mathrm{Pt}}\right)$ and $\mathrm{I} / \mathrm{C}$ mass ratios, their electrochemically active surface area (ECSA) determined by cyclic voltammetry, and their ORR mass activity at $0.9 \mathrm{~V}$, $80^{\circ} \mathrm{C}$, and $100 \% \mathrm{RH}$ at the experimentally used $\mathrm{H}_{2}$ and $\mathrm{O}_{2}$ partial pressures of $123 \mathrm{kPa}_{a b s, \text { inlet }}\left(i_{\mathrm{m}}\right)$ as well as extrapolated to $\mathrm{H}_{2}$ and $\mathrm{O}_{2}$ partial pressures of $103 \mathrm{kPa}_{\mathrm{abs}}$,inlet $\left(\mathrm{i}_{\mathrm{m}}{ }^{*}\right)$. The last column shows the Tafel slopes. Mass activities and Tafel slopes were obtained from Figure 3b, i.e., after correction for the HFR, the effective proton conduction resistance in the electrodes, and $\mathrm{H}_{2}$ crossover correction. The indicated variation represents the standard deviation from two independent measurements.

\begin{tabular}{ccccccc} 
Catalyst & $\mathrm{I} / \mathrm{C}$ & $\begin{array}{c}\mathrm{L}_{\mathrm{Pt}} \\
{\left[\mu \mathrm{g}_{\mathrm{Pt}} / \mathrm{cm}^{2}{ }_{\text {geo }}\right]}\end{array}$ & $\begin{array}{c}\mathrm{ECSA} \\
{\left[\mathrm{m}^{2} / \mathrm{g}_{\mathrm{Pt}}\right]}\end{array}$ & $\begin{array}{c}\mathrm{i}_{\mathrm{m}} \\
{\left[\mathrm{A} / \mathrm{g}_{\mathrm{Pt}}\right]}\end{array}$ & $\begin{array}{c}\mathrm{i}_{\mathrm{m}} * \\
{\left[\mathrm{~A} / \mathrm{g}_{\mathrm{Pt}}\right]}\end{array}$ & $\begin{array}{c}\mathrm{TS} \\
{[\mathrm{mV} / \mathrm{dec} .]}\end{array}$ \\
\hline $\mathrm{Pt} / \mathrm{V}$ & 0.65 & $68 \pm 1$ & $52 \pm 2$ & $119 \pm 2$ & $93 \pm 2$ & $76 \pm 1$ \\
$\mathrm{Pt} / \mathrm{V}-\mathrm{NH}_{\mathrm{x}}$ & 0.65 & $78 \pm 2$ & $55 \pm 1$ & $110 \pm 6$ & $86 \pm 6$ & $76 \pm 0$ \\
$\mathrm{Pt} / \mathrm{V}-\mathrm{NH}_{\mathrm{x}}$ & 0.40 & $74 \pm 2$ & $56 \pm 3$ & $127 \pm 2$ & $100 \pm 2$ & $72 \pm 1$ \\
$\mathrm{Pt} / \mathrm{V}-\mathrm{NH}_{\mathrm{x}}$ & 0.25 & $68 \pm 4$ & $59 \pm 4$ & $146 \pm 8$ & $105 \pm 8$ & $74 \pm 1$
\end{tabular}



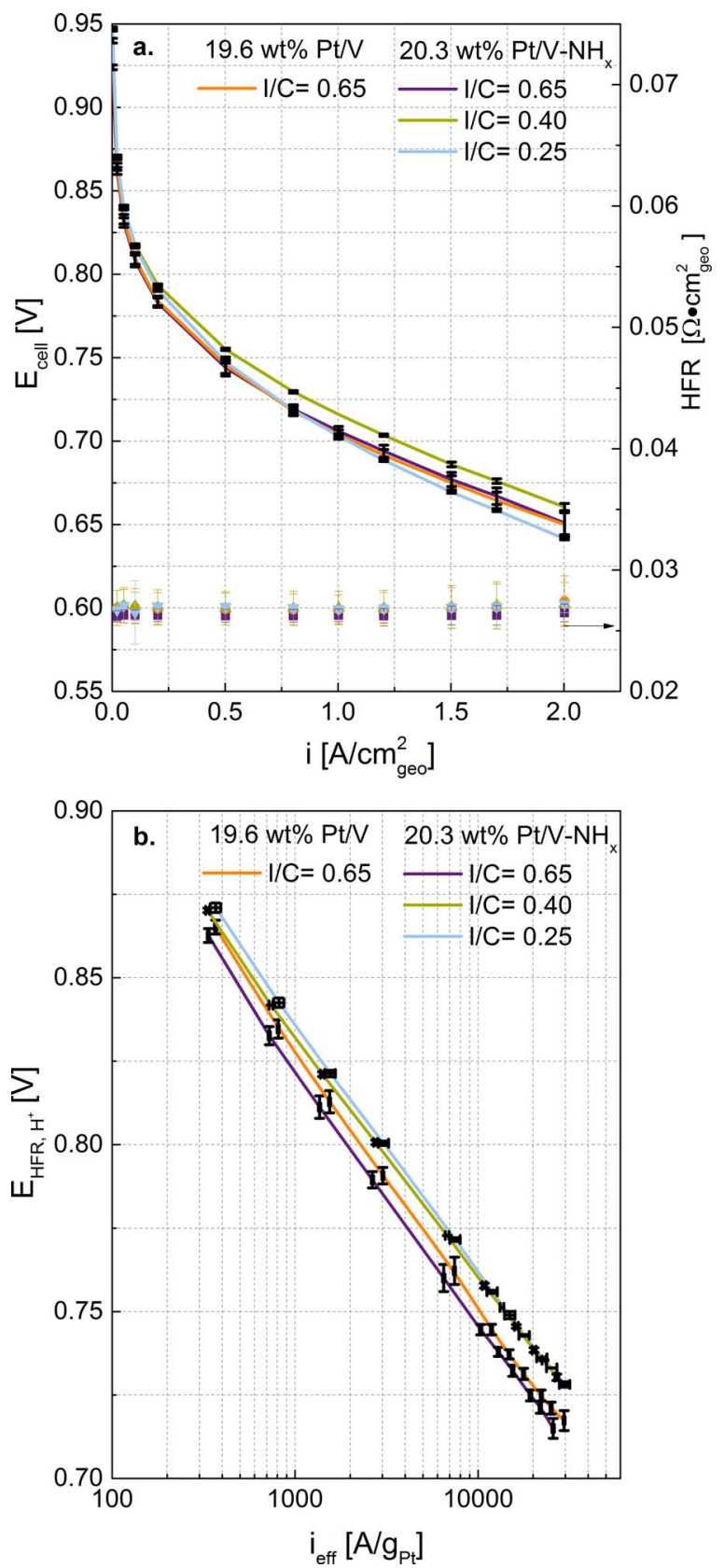

Figure 3. $\mathrm{H}_{2} / \mathrm{O}_{2}(2000 / 5000 \mathrm{nccm})$ differential flow performance of MEAs with ultra-low Pt cathode loadings $\left(68-78 \mu \mathrm{g}_{\mathrm{Pt}} / \mathrm{cm}^{2}\right.$ geo ; see Table IV) at $80^{\circ} \mathrm{C}$, $100 \% \mathrm{RH}$, and $P_{\text {cell }}=170 \mathrm{kPa}_{\text {abs,inlet }}$ for the $19.6 \mathrm{wt} \% \mathrm{Pt} / \mathrm{V}$ cathode catalyst at an I/C mass ratio of 0.65 (orange curves) and for the $20.3 \mathrm{wt} \% \mathrm{Pt} / \mathrm{V}$ $\mathrm{NH}_{\mathrm{x}}$ cathode catalyst at $\mathrm{I} / \mathrm{C}$ mass ratios of 0.65 (purple), 0.40 (green), and 0.25 (light blue): a. uncorrected performance curves (left y-axis) with their corresponding HFR (right y-axis); b. performance curves referenced to the Ptmass normalized current density corrected for $\mathrm{HFR}, \mathrm{H}^{+}$conduction resistance in the cathode $\left(\mathrm{R}_{\mathrm{H}+\text {,cath }}^{\text {eff }}\right)$, and the $\mathrm{H}_{2}$ crossover current. Anode Pt loading were $0.1 \mathrm{mg}_{\mathrm{Pt}} / \mathrm{cm}^{2}$ geo and the error bars correspond to the standard deviation between two independent measurements on two different MEAs.

and are thus quite close to their theoretical value of $70 \mathrm{mV} / \mathrm{dec}$. (i.e., based on a transfer coefficient of $\alpha=1$ ), as reported by Neyerlin et al. ${ }^{38}$ Larger Tafel slopes of $\sim 80 \mathrm{mV} / \mathrm{dec}$. for $0.05 \mathrm{mg}_{\mathrm{Pt}} / \mathrm{cm}^{2}$ cathodes were observed by Owejan et al. ${ }^{11}$ (evaluated from their transportcorrected $\mathrm{H}_{2} / \mathrm{O}_{2}$ polarization curves between 40 and $800 \mathrm{~mA} / \mathrm{cm}^{2}$ geo $)$. Considering that residual and/or not accurately corrected for transport resistances always lead to higher apparent Tafel slopes, we ascribe the slightly higher Tafel slopes in their study to unaccounted transport losses, possibly due to not fully optimized electrodes (e.g., inhomogeneous ionomer distribution), which were shown to yield higher Tafel slopes. $^{39}$

To estimate $\mathrm{H}_{2}$ /air performance of MEAs by differential flow experiments, the stack inlet conditions and the stack outlet conditions are commonly simulated by using $21 \%$ and $10 \% \mathrm{O}_{2}$, respectively ${ }^{41}$ (the latter corresponds to an air stoichiometry of $\sim 1.9$ ). Thus, polarization curves were measured under differential flows of $21 \%$ and $10 \% \mathrm{O}_{2}$ in $\mathrm{N}_{2}$ at $80^{\circ} \mathrm{C}, 100 \% \mathrm{RH}$, and $170 \mathrm{kPa}_{\mathrm{abs} \text {,inlet. }}$. Figure 4 shows the effect of the carbon support functionalization on the MEA performance for $21 \% \mathrm{O}_{2}$ (dashed lines) and $10 \% \mathrm{O}_{2}$ (solid lines). The performance at $0.6 \mathrm{~V}$ for the $19.6 \mathrm{wt} \% \mathrm{Pt} / \mathrm{V}$ catalyst (orange lines) is in excellent agreement with recently published data under essentially identical conditions (differential flow, $80^{\circ} \mathrm{C}, 100 \% \mathrm{RH}$, and 150 $\mathrm{kPa}_{\text {abs,outlet }}$ ) for a graphitized carbon supported Pt catalyst at the same loading ${ }^{41}$ : $1.4 \mathrm{~A} / \mathrm{cm}^{2}{ }_{\text {geo }}$ (our data) vs $1.3 \mathrm{~A} / \mathrm{cm}^{2}{ }_{\text {geo }}$ at $21 \% \mathrm{O}_{2}$ and 0.78 $\mathrm{A} / \mathrm{cm}^{2}{ }_{\text {geo }}$ (our data) vs. $0.83 \mathrm{~A} / \mathrm{cm}^{2}{ }_{\text {geo }}$ at $10 \% \mathrm{O}_{2}$. Significantly better performance, however, is observed with our $\mathrm{NH}_{\mathrm{x}}$-functionalized catalyst $\left(1.65 \mathrm{~A} / \mathrm{cm}^{2}{ }_{\text {geo }}\right.$ at $21 \% \mathrm{O}_{2}$ and $0.91 \mathrm{~A} / \mathrm{cm}^{2}$ geo at $\left.10 \% \mathrm{O}_{2}\right)$. Kongkanand et al. ${ }^{41}$ showed that the carbon support surface area (particularly the fraction of surface in micropores) and the location of the $\mathrm{Pt}$ particles on the primary carbon particles can significantly influence the local $\mathrm{O}_{2}$ mass transport resistance and in turn the performance of the MEA. Pt particles that are located in the interior of the catalyst $(\mathrm{Pt}$ supported on a high-surface area carbon, Pt/MSC-a), versus Pt particles located exclusively on the exterior of the carbon (Pt supported on a graphitized carbon support, $\mathrm{Pt} / \mathrm{GrC}$-a) can significantly influence the performance under low $\mathrm{O}_{2}$ partial pressure and low Pt loadings.

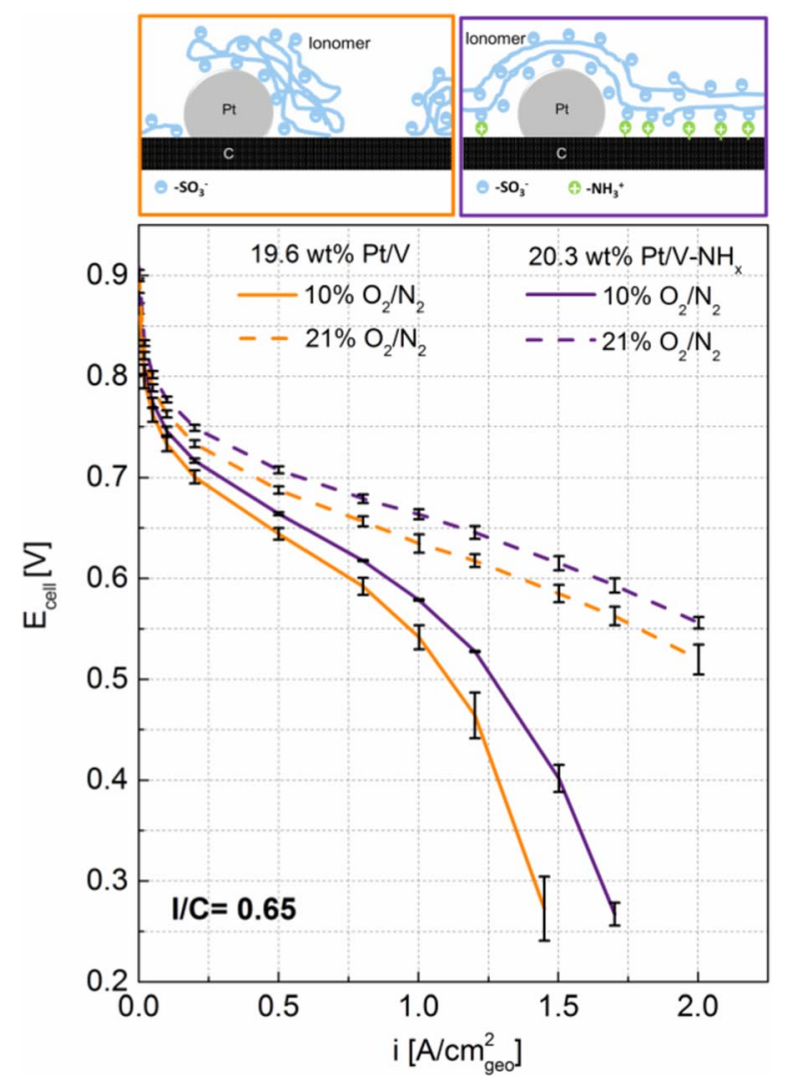

Figure 4. Differential flow polarization curves at $80^{\circ} \mathrm{C}$ and $100 \% \mathrm{RH}$ of 19.6 wt $\% \mathrm{Pt} / \mathrm{V}$ (orange) and $20.3 \mathrm{wt} \% \mathrm{Pt} / \mathrm{V}-\mathrm{NH}_{\mathrm{x}}$ (purple) cathodes with $\mathrm{I} / \mathrm{C}$ of 0.65 with $21 \% \mathrm{O}_{2}$ (dashed lines) and $10 \% \mathrm{O}_{2}$ (solid lines) in the cathode gas feed at a cell pressure of $170 \mathrm{kPa}_{\mathrm{abs} \text {,inlet }}$. Cathode Pt loadings were $68 \pm 1$ and $78 \pm 2$ $\mu \mathrm{g}_{\mathrm{Pt}} / \mathrm{cm}^{2}{ }_{\text {geo }}$ for the $\mathrm{Pt} / \mathrm{V}$ and the $\mathrm{Pt} / \mathrm{V}-\mathrm{NH}_{\mathrm{x}}$ electrodes, respectively. The error bars correspond to the standard deviation for repeat measurements with two different MEAs. Schemes: sketch of the hypothesized ionomer distribution on the different carbon supports. 
In our study, the $\mathrm{V}-\mathrm{NH}_{\mathrm{x}}$ has a surface area of $175 \mathrm{~m}^{2} / \mathrm{g}_{\mathrm{C}}$, out of which $75 \mathrm{~m}^{2} / \mathrm{g}_{\mathrm{C}}$ are micropores, so roughly $40 \%$ less micropores are accessible on the $\mathrm{V}-\mathrm{NH}_{\mathrm{x}}$ compared to the V support. Part of the performance improvement which is observed for the $\mathrm{Pt} / \mathrm{V}-\mathrm{NH}_{\mathrm{x}}$ vs the $\mathrm{Pt} / \mathrm{V}$ could be attributed to the reduced micropores of the carbon support. Nevertheless, by comparing the performance of the $\mathrm{GrC}-\mathrm{a}\left(100 \mathrm{~m}^{2} / \mathrm{g}_{\mathrm{C}}\right)$ used in the study by Kongkanand et al. which has no micropores, with the $\mathrm{V}-\mathrm{NH}_{\mathrm{x}}$ supported catalyst, the latter exhibits better performance under the same operating conditions. This indicates that the performance improvement between $\mathrm{Pt} / \mathrm{V}-\mathrm{NH}_{\mathrm{x}}$ and $\mathrm{Pt} / \mathrm{V}$ cannot be solely attributed to the difference of microporosity of the carbon supports.

We hypothesize that this is due to a more homogeneous ionomer distribution on the $\mathrm{NH}_{\mathrm{x}}$-functionalized carbon support (illustrated by the sketches in Figure 4), which would result in a homogeneous ionomer film thickness over the whole electrode. This hypothesis is based on the known coulombic interaction between the $\mathrm{NH}_{\mathrm{x}}$ groups on the carbon support with the $\mathrm{SO}_{3}{ }^{-}$groups of the ionomer ${ }^{20,21}$ (Figure 4, purple-framed sketch).

In the case of $\mathrm{Pt} / \mathrm{V}$, the ionomer distribution is expected to be more inhomogeneous with a more random ionomer film thickness, which would lead to a high $\mathrm{O}_{2}$ transport resistance in the regions where the ionomer film is thicker and to high proton conduction resistance in the regions where the ionomer film is thinner (Figure 4, orange-framed sketch). The latter would not only be expected to result in a performance decrease at high current densities and low oxygen concentrations, but also to larger discrepancies between transport resistance corrected performance curves and the kinetically predicted performance curve.

The above hypothesis, namely that the performance difference between the $\mathrm{Pt} / \mathrm{V}$ and the $\mathrm{Pt} / \mathrm{V}-\mathrm{NH}_{\mathrm{x}}$ is related to a difference in ionomer homogeneity and thus improved oxygen mass transport is further supported by the dependence of the performance to the $\mathrm{I} / \mathrm{C}$ ratio, evaluated in Figure 5 for the $20.3 \mathrm{wt} \% \mathrm{Pt} / \mathrm{V}-\mathrm{NH}_{\mathrm{x}}$ catalyst: as the $\mathrm{I} / \mathrm{C}$ is decreased

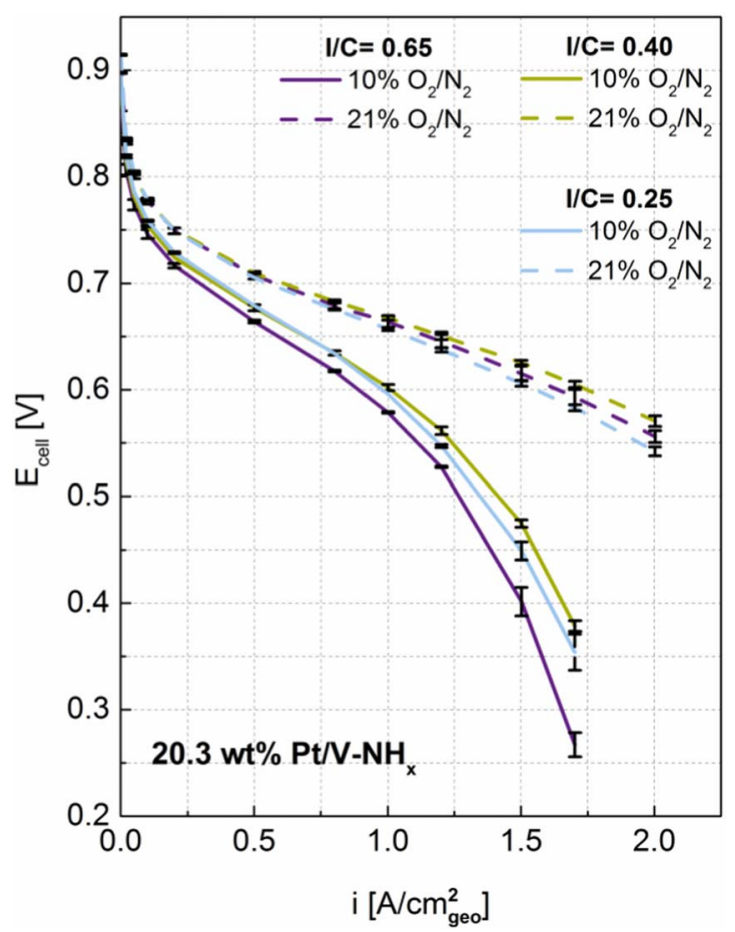

Figure 5. Differential flow polarization curves at $80^{\circ} \mathrm{C}$ and $100 \% \mathrm{RH}$ of 20.3 wt $\% \mathrm{Pt} / \mathrm{V}-\mathrm{NH}_{\mathrm{x}}$ cathodes with $\mathrm{I} / \mathrm{C}$ mass ratios of 0.65 (purple), 0.4 (green) and 0.25 (blue) with $21 \%$ (dashed lines) and $10 \% \mathrm{O}_{2}$ (solid lines) in the cathode gas feed at a cell pressure of $170 \mathrm{kPa}_{\mathrm{abs} \text {,inlet }}$. Cathode Pt loadings were $78 \pm$ $2,74 \pm 2$, and $68 \pm 4 \mu \mathrm{g}_{\mathrm{Pt}} / \mathrm{cm}^{2}$ geo for the MEAs with ionomer mass ratios of $0.65,0.40$, and 0.25 , respectively. The error bars correspond to the standard deviation for repeat measurements with two different MEAs.
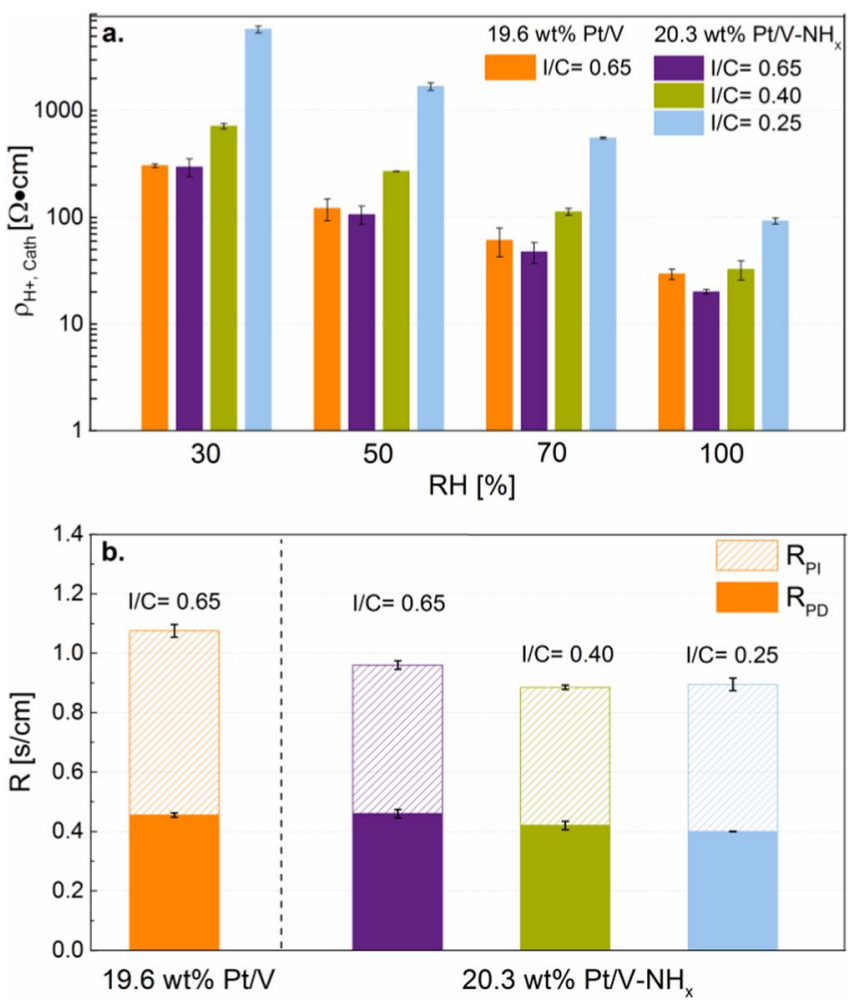

Figure 6. The effect of the cathode catalyst layer composition on: a. the cathode proton resistivity $\left(\rho_{\mathrm{H}+\text {,eff. }}\right)$ at different relative humidities $(\mathrm{RH})$ and different $\mathrm{I} / \mathrm{C}$ ratios; $\mathrm{b}$. the total oxygen mass transport resistance $\left(\mathrm{R}_{\mathrm{total}} \equiv\right.$ sum of the solid and hatched bars), which can be separated into a pressure dependent term $\left(\mathrm{R}_{\mathrm{PD}}\right)$ and a pressure independent term $\left(\mathrm{R}_{\mathrm{PI}}\right)$. The error bars correspond to the standard deviation between independent measurements with two different MEAs.

to 0.40 (green lines), the performance at $0.6 \mathrm{~V}$ further increases to 1.75 $\mathrm{A} / \mathrm{cm}^{2}$ geo at $21 \% \mathrm{O}_{2}$ and $1.0 \mathrm{~A} / \mathrm{cm}^{2}{ }_{\text {geo }}$ at $10 \% \mathrm{O}_{2}$, which can only be attributed to the $\mathrm{O}_{2}$ permeability through the ionomer film. ${ }^{9}$ As the $\mathrm{I} / \mathrm{C}$ ratio is further decreased to 0.25 , the performance decreases due to poor proton conductivity in the catalyst layer, as will be quantified in the following.

The proton resistivity of the different cathodes was measured according to the method developed by Liu et al. ${ }^{43}$ As shown in Figure $6 \mathrm{a}$, the cathode proton resistivity strongly depends on $\mathrm{RH}$ and the cathode $\mathrm{I} / \mathrm{C}$ ratio, as what would be expected. ${ }^{43}$ Comparing the $\mathrm{Pt} / \mathrm{V}$ and the $\mathrm{Pt} / \mathrm{V}-\mathrm{NH}_{\mathrm{x}}$ based MEAs with an $\mathrm{I} / \mathrm{C}$ ratio of 0.65 , the difference between their proton resistivities at the various $\mathrm{RH}$ values is identical within the error of the measurement. It is known that the intrusion of the ionomer into the micropores of the primary carbon particles reduces the ionomer film thickness on the external surface of the carbon support. ${ }^{42}$ Thus, to estimate the average ionomer film thickness at the external carbon surface, it is necessary to determine the effective $\mathrm{I} / \mathrm{C}$ ratio $\left(\mathrm{I} / \mathrm{C}_{\text {eff. }}\right)$ from the overall $\mathrm{I} / \mathrm{C}$ ratio, as was done by Liu et al. ${ }^{42}$ Using this approach, we estimated the effective ionomer thickness $\left(t_{\text {ionomer,eff. }}\right)$ by considering the cumulative pore volume in pores smaller than $3 \mathrm{~nm}$, which was obtained from Figure S2 (highlighted). As shown in Table $\mathrm{V}$, the effective ionomer film thickness at the $\mathrm{I} / \mathrm{C}$ ratio of 0.65 is similar for the catalyst with the aminated $(\mathrm{Pt} / \mathrm{V}$ $\mathrm{NH}_{\mathrm{x}}$ ) and the untreated carbon $(\mathrm{Pt} / \mathrm{V})$. In summary, even though one might have expected that a less homogeneous ionomer film at equal average film thickness (i.e., at equal $t_{\text {ionomer,eff. }}$ ) would lead to a higher proton resistivity, this is not the case. However, differences in proton resistivity would also be expected to be negligible for inhomogeneous ionomer films, as long as there exists a continuous ionomer pathway throughout the electrode. Therefore, the homogeneity of the ionomer on the catalyst surface cannot necessarily be deduced from proton 
Table V. Effective $\mathrm{I} / \mathrm{C}$ ratio ( $\left.\mathrm{I} / \mathrm{C}_{\text {eff. }}\right)$ and effective ionomer thickness $\left(t_{\text {ionomer,eff. }}\right)$ for cathodes with different catalysts and overall I/C ratios, calculated by considering ionomer absorption into micropores of $\leq \mathbf{3} \mathrm{nm}$.

\begin{tabular}{cccc} 
Catalyst & $\mathrm{I} / \mathrm{C}$ & $\mathrm{I} / \mathrm{C}_{\text {eff. }}$ & t $_{\text {ionomer,eff. }}[\mathrm{nm}]$ \\
\hline $\mathrm{Pt} / \mathrm{V}(\mathrm{TKK})$ & 0.65 & 0.53 & 2.6 \\
$\mathrm{Pt} / \mathrm{V}-\mathrm{NH}_{\mathrm{x}}$ & 0.65 & 0.58 & 2.8 \\
$\mathrm{Pt} / \mathrm{V}-\mathrm{NH}_{\mathrm{x}}$ & 0.40 & 0.33 & 1.6 \\
$\mathrm{Pt} / \mathrm{V}-\mathrm{NH}_{\mathrm{x}}$ & 0.25 & 0.18 & 0.9
\end{tabular}

resistivity measurements. Decreasing the $\mathrm{I} / \mathrm{C}$ ratio of the $\mathrm{Pt} / \mathrm{V}-\mathrm{NH}_{\mathrm{x}}$ cathodes, the proton resistivity increases substantially, as expected for a decrease in the effective ionomer thickness. ${ }^{43,44}$

To quantify the oxygen mass transport resistance $\left(\mathrm{R}_{\text {total }}\right), \mathrm{O}_{2}$ limiting current measurements were performed. ${ }^{5}$ Since the same gas diffusion layer (GDL) was used for all measurements, one would expect that any differences observed originate from the changes in the catalyst layers and that the contributions from the diffusion medium and the microporous layer remain unchanged. To examine this aspect, the total oxygen mass transport resistance can be separated into a pressure dependent resistance $\left(\mathrm{R}_{\mathrm{PD}}\right)$ and a pressure independent resistance $\left(\mathrm{R}_{\mathrm{PI}}\right)$, which can be quantified by conducting limiting current measurements at various $\mathrm{O}_{2}$ concentrations and at different cell pressures. Here, the $\mathrm{R}_{\mathrm{PD}}$ term describes Fickian intermolecular gas diffusion through larger pores ( $>100 \mathrm{~nm}$ diameter), while the $R_{\mathrm{PI}}$ term comprises Knudsen diffusion in small pores of the microporous layer and the catalyst layers $(<100 \mathrm{~nm}$ diameter) as well as diffusion through the ionomer film covering the Pt particles. ${ }^{11}$

Figure $6 \mathrm{~b}$ shows the effect of the catalyst layer composition on the total transport resistance $\mathrm{R}_{\text {total }}$, which is the sum of $\mathrm{R}_{\mathrm{PD}}$ (solid bars) and $\mathrm{R}_{\mathrm{PI}}$ (hatched bars). For all MEAs, $\mathrm{R}_{\mathrm{PD}}$ was relatively constant between $0.41-0.45 \mathrm{~s} / \mathrm{cm}$, i.e., essentially identical within the error of the measurement, and thus consistent with the fact that the same diffusion media were used for all experiments. This suggests that the clearly lower total transport resistance for the $20.3 \mathrm{wt} \% \mathrm{Pt} / \mathrm{V}-\mathrm{NH}_{\mathrm{x}}$ cathode with an I/C mass ratio of 0.65 (purple bars) compared to the $19.6 \mathrm{wt} \% \mathrm{Pt} / \mathrm{V}$ catalyst with the same I/C (orange bars) must be due to a lower pressure independent oxygen transport resistance $\left(\mathrm{R}_{\mathrm{PI}}\right)$ of the former, which we ascribe to a more homogeneous ionomer distribution on the $\mathrm{NH}_{\mathrm{x}}$-functionalized carbon support. As the I/C mass ratio of $20.3 \mathrm{wt} \% \mathrm{Pt} / \mathrm{V}-\mathrm{NH}_{\mathrm{x}}$ cathodes is reduced from 0.65 to 0.40 , corresponding to reduction of the estimated ionomer film thickness from $\sim 2.8$ to $\sim 1.6 \mathrm{~nm}$ (see Table $\mathrm{V}$ ), $\mathrm{R}_{\text {total }}$ and $\mathrm{R}_{\mathrm{PI}}$ decrease slightly, qualitatively consistent with a very recent report by Putz et al., ${ }^{45}$ who showed a decrease of $\mathrm{R}_{\mathrm{PI}}$ when the effective ionomer thickness is decreased from $\sim 3.5$ to $\sim 2 \mathrm{~nm}$. In their study, a further decrease of the effective ionomer thickness down to $\sim 0.5 \mathrm{~nm}$ did not lead to any further decrease in $\mathrm{R}_{\mathrm{PI}}$, identical to what we observe when decreasing the $\mathrm{I} / \mathrm{C}$ ratio from 0.40 to 0.25 (blue bars), i.e., from an effective ionomer film thickness of $\sim 1.6 \mathrm{~nm}$ to $\sim 0.9 \mathrm{~nm}$. While this independence of $R_{P I}$ from the ionomer film thickness at very low $\mathrm{I} / \mathrm{C}$ ratios is not yet understood, the data in Figure $6 \mathrm{~b}$ clearly demonstrate that cathodes prepared with $\mathrm{NH}_{\mathrm{x}}$-functionalized carbon supports exhibit lower values of $R_{P I}$ (and $R_{\text {total }}$ ), which is consistent with our hypothesis that a more homogeneous ionomer distribution can be achieved by $\mathrm{NH}_{\mathrm{x}}$-functionalized carbon supports.

\section{Discussion}

The above presented MEA performance data clearly demonstrate superior $\mathrm{H}_{2}$ /air performance at high current densities of the cathodes based on $\mathrm{NH}_{\mathrm{x}}$-functionalized carbon supports (see dashed lines in Figures 4 and 5), which is consistent with their lower oxygen mass transport resistance (Figure 6b). Based on the above data, we hypothesize that this is due to a more homogeneous distribution of the ionomer in the MEA. In this case, however, one would expect a more quanti- tative agreement between the ORR kinetics limited performance and the transport-corrected $\mathrm{H}_{2}$ /air performance curves, as all transport resistance measurements and voltage loss corrections are based on assuming a uniform ionomer distribution in the electrode. In order to examine this assumption, we will first correct the $\mathrm{H}_{2}$ /air polarization curves shown in Figures 4 and 5 (dashed lines) by the ohmic losses due to membrane and electronic resistances (i.e., by the HFR), by the total oxygen transport resistance (i.e., by $\mathrm{R}_{\text {total }}$ shown in Figure $6 \mathrm{~b}$ ), and by the effective proton conduction resistance in the cathode $\left(\mathrm{R}_{\mathrm{H}+\text {,cath }}^{\text {eff }}\right)$; this will then be compared to the performance predicted by the ORR kinetics (see Table IV).

The transport-corrected $\mathrm{H}_{2} /$ air cell voltage, $\mathrm{E}_{\text {cell,tx-corr }}$, is described by:

$$
\mathrm{E}_{\text {cell,tx-corr }}=\mathrm{E}_{\text {cell }}+\mathrm{i}_{\text {geo }} \cdot \mathrm{HFR}+\Delta \mathrm{E}_{\mathrm{O} 2-\mathrm{tx}}+\mathrm{i}_{\text {geo }} \cdot \mathrm{R}_{\mathrm{H}+\text {,cath }}^{\text {eff }}
$$

where $\mathrm{U}_{\text {cell }}$ is the measured $\mathrm{H}_{2}$ /air cell voltage, $\Delta \mathrm{U}_{\mathrm{O} 2 \text {-tx }}$ is the total oxygen transport induced voltage loss, and $\mathrm{R}_{\mathrm{H}+\text {, cath }}^{\text {eff }}$ is the effective proton transport resistance in the cathode electrode. As shown by Neyerlin et al., ${ }^{46}$ the latter is related to the measured proton conduction resistance in the cathode, $\mathrm{R}_{\mathrm{H}+\text {, cath }}$, by:

$$
\mathrm{R}_{\mathrm{H}+\text {,cath }}^{\text {eff }}=\mathrm{R}_{\mathrm{H}+\text {, cath }} /(3+\xi)
$$

where $\zeta$ is a scaling parameter which depends on $\left(i_{\text {geo }} \cdot R_{H+, \text { cath }}\right)$ divided by the ORR Tafel slope. ${ }^{46}$ The voltage loss due to the total oxygen mass transport resistance $\left(R_{\text {total }}\right)$ is calculated using Equation 3, derived by Zihrul et al.: ${ }^{47}$

$$
\Delta E_{O 2-t x}=\frac{R T}{F} \cdot\left(\frac{1}{4}+\frac{\gamma}{\alpha}\right) \cdot \ln \left(\frac{p_{O 2, \text { channel }}-\frac{R T}{4 F} \cdot R_{\text {total }} \cdot i_{\text {geo }}}{p_{\text {O2,channel }}}\right)
$$

where, $\gamma$ is the ORR reaction order with respect to oxygen partial pressure $(\gamma=0.54),{ }^{38} \alpha$ is the transfer coefficient $(\alpha=1),{ }^{38} R$ is ideal gas constant, $T$ is the cell temperature, and $p_{O 2, \text { channel }}$ is the partial pressure of $\mathrm{O}_{2}$ in the channel of the flow field. The transport corrected $\mathrm{H}_{2}$ /air performance curves calculated from the $\mathrm{H}_{2}$ /air performance and HFR data as well as from the measured $\mathrm{R}_{\text {total }}$ and $\mathrm{R}_{\mathrm{H}+\text {,cath }}$ values (for the reader's convenience, all tabulated in the SI) using Equations 1-3 are shown in Figure 7a for the four different cathodes.

These can now be compared to the purely kinetically limited ORR performance, $\mathrm{U}_{\mathrm{ORR}}$, obtained from the reversible cell voltage, $\mathrm{E}_{\mathrm{rev}}$, and the ORR overpotential, $\eta_{\mathrm{ORR}}$ :

$$
E_{O R R}=E_{\text {rev }}-\eta_{\text {ORR }}
$$

whereby the reversible cell voltage at the $\mathrm{H}_{2}$ /air operating conditions is $\mathrm{E}_{\mathrm{rev}}=1.17 \mathrm{~V}$ (based on Equation 2 in Ref. 38. Under the assumption that the ORR kinetics follow the simple Tafel kinetics with a constant Tafel slope of $2.303 \cdot R \cdot T /(\alpha \cdot F), \mathrm{U}_{\mathrm{ORR}}$ can be related to the ORR mass activity at the reference conditions of $0.9 \mathrm{~V}, T^{*}=80^{\circ} \mathrm{C}$, and $\mathrm{p}_{\mathrm{H} 2}^{*}$ $=\mathrm{p}_{\mathrm{O} 2}^{*}=103 \mathrm{kPa}_{\mathrm{abs}}$ (corresponding to $\mathrm{i}_{\mathrm{m}}^{*}$ in units of $\mathrm{A} / \mathrm{g}_{\mathrm{Pt}}$; see Table IV) by Equation 11 in Neyerlin et al. ${ }^{38}$ :

$$
\begin{aligned}
& \mathrm{E}_{\mathrm{ORR}}=0.900 \mathrm{~V}-\frac{2.303 \cdot \mathrm{R} \cdot \mathrm{T}}{\alpha \cdot \mathrm{F}} \\
& \cdot \log \left(\frac{\mathrm{i}_{\mathrm{eff}}}{\mathrm{i}_{\mathrm{m}}^{*} \cdot \mathrm{L}_{\mathrm{Pt}} \cdot 10^{-3} \cdot\left(\frac{\mathrm{P}_{\mathrm{O} 2}}{\mathrm{P}_{\mathrm{O} 2}^{*}}\right)^{\mathrm{m}} \cdot\left(\frac{\mathrm{P}_{\mathrm{H} 2}}{\mathrm{P}_{\mathrm{H} 2}^{*}}\right)^{\alpha / 2} \cdot \exp \left[\frac{\mathrm{E}_{\mathrm{act}}^{(0.9 \mathrm{~V})}}{\mathrm{R} \cdot \mathrm{T}} \cdot\left(1-\frac{\mathrm{T}}{\mathrm{T}^{*}}\right)\right]}\right)
\end{aligned}
$$

where $\alpha=1\left(\equiv 70 \mathrm{mV} /\right.$ dec. at $\left.80^{\circ} \mathrm{C}\right), \mathrm{L}_{\mathrm{Pt}}$ is the cathode platinum loading (in $\mathrm{mg}_{\mathrm{Pt}} / \mathrm{cm}^{2}{ }_{\text {geo }}$ ), $p_{\mathrm{O} 2}$ and $p_{\mathrm{H} 2}$ are the actual $\mathrm{O}_{2}$ and $\mathrm{H}_{2}$ partial pressures, respectively, $\mathrm{m}$ is the reaction order with respect to $\mathrm{O}_{2}(\mathrm{~m}$ $=0.79)^{38}$ and $\mathrm{E}_{\mathrm{act}}^{(0.9 \mathrm{~V})}$ is the activation energy at $0.9 \mathrm{~V}$ (note that this last term in Equation 5 vanishes for $T=T^{*}$ ). The average of the ORR kinetics limited performance curves derived from Equation 5 using the ORR mass activities and Pt loadings of the different MEAs $\left(\mathrm{i}_{\mathrm{m}}^{*}\right.$ and $L_{P t}$, see Table IV) is plotted as black line in Figure 7a, whereby the error bars represent the standard deviation between the calculated ORR curves for each MEA. 

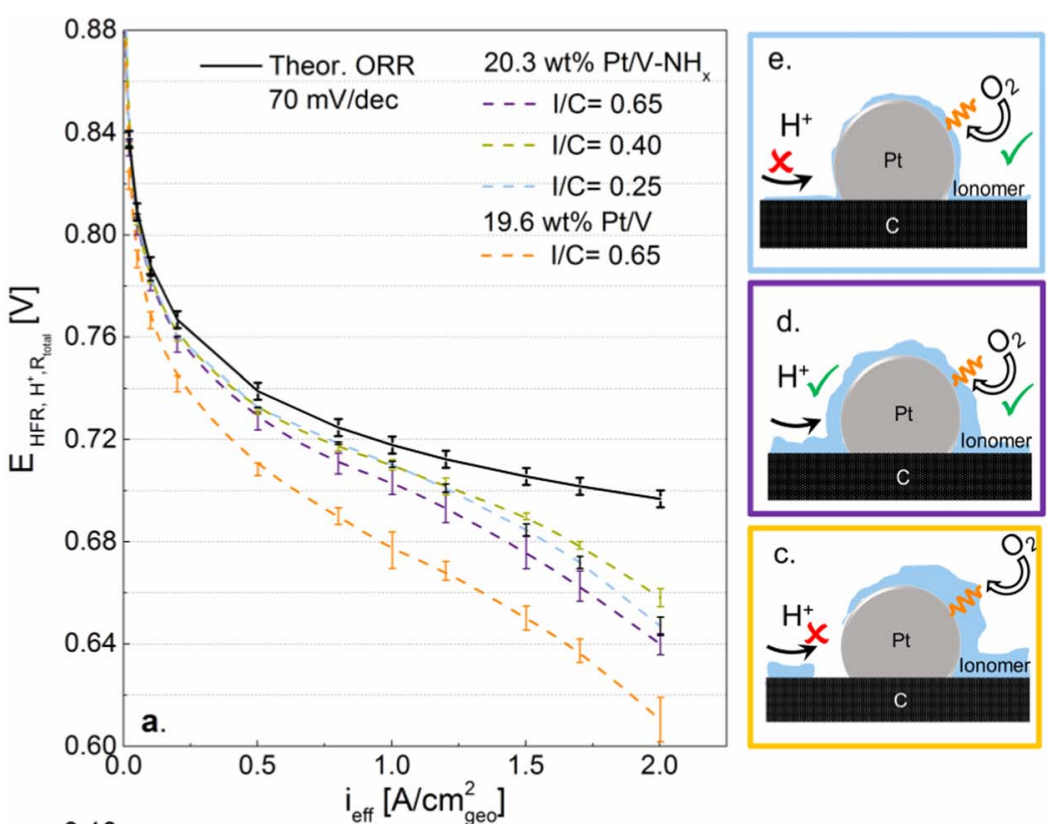

Figure 7. a. Transport-corrected $\mathrm{H}_{2} /$ air performance curves derived from Equation 1 for the various MEA types (dashed lines) and average value of the purely ORR kinetics limited performance curve derived from Equation 5; b. unaccounted voltage losses for each MEA type; c.-e. schematic illustration of the effect of the ionomer distribution and thickness on proton conductivity and mass transport. The error bars correspond to the standard deviation for repeat measurements with two different MEAs. Measurement conditions: $\mathrm{H}_{2} /$ air at differential flow conditions, $80^{\circ} \mathrm{C}, 100 \% \mathrm{RH}, 170 \mathrm{kPa}_{\mathrm{abs}}$,inlet

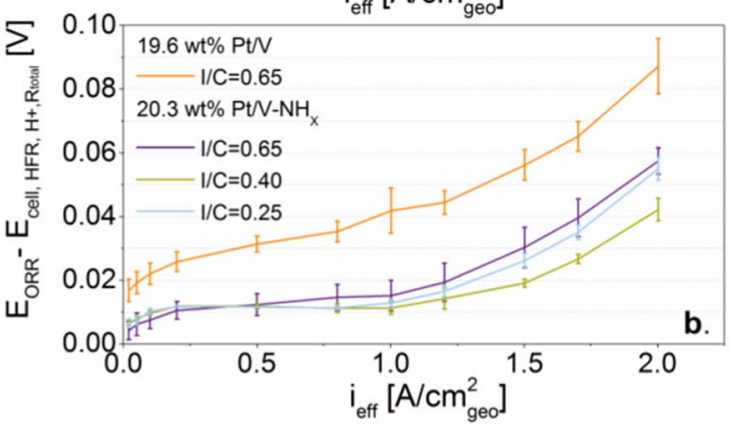

We will first discuss the outcome of this analysis by comparing the two different catalysts in cathodes with the same I/C ratio of 0.65 (orange and purple lines in Figure 7a). Quite clearly, the $\mathrm{Pt} / \mathrm{V}-\mathrm{NH}_{\mathrm{x}}$ based MEAs exhibit lower unaccounted voltage losses, i.e., their transportcorrected performance curve is closer to the purely kinetically limited ORR performance curve (black line). To more clearly illustrate the extent of unaccounted voltage losses, Figure $7 \mathrm{~b}$ depicts the unaccounted loss of each MEA, obtained by subtracting the transport-corrected performance curves from the ORR kinetics limited performance of the same MEA. Figure 7b illustrates that the unaccounted voltage losses of the $\mathrm{Pt} / \mathrm{V}-\mathrm{NH}_{\mathrm{x}}$ based MEAs (purple line) are substantially smaller than those of the MEAs based on $\mathrm{Pt} / \mathrm{V}$ (orange line), which we attribute to a more homogeneous ionomer distribution and thus more homogeneous local ionomer film thickness on the former, illustrated schematically in Figures $7 \mathrm{~d}\left(\mathrm{Pt} / \mathrm{V}-\mathrm{NH}_{\mathrm{x}}\right)$ and $7 \mathrm{c}(\mathrm{Pt} / \mathrm{V})$. While for the case of the $\mathrm{V}-\mathrm{NH}_{\mathrm{x}}$ supported catalyst the unaccounted voltage losses decrease as the $\mathrm{I} / \mathrm{C}$ ratio decreases.

Under the assumption of a homogeneous ionomer distribution, decreasing the $\mathrm{I} / \mathrm{C}$ ratio would result in thinner ionomer film over the $\mathrm{Pt}$ particles, thereby facilitating higher $\mathrm{O}_{2}$ permeability to the $\mathrm{Pt} /$ ionomer interface. This is consistent with the lower oxygen mass transport resistance observed for the $\mathrm{Pt} / \mathrm{V}-\mathrm{NH}_{\mathrm{x}}$ based cathodes with an I/C ratio of 0.4 (see Figure 6b) and with their much reduced unaccounted voltage losses (see green line in Figure $7 b$ ). Therefore, from this analysis we can conclude that the ionomer distribution and thickness is a key factor in controlling oxygen mass transport resistances. On the other hand, for the $\mathrm{Pt} / \mathrm{V}-\mathrm{NH}_{\mathrm{x}}$ based cathodes with an $\mathrm{I} / \mathrm{C}$ of 0.25 , which corresponds to an effective ionomer film thickness of $\sim 0.9$ $\mathrm{nm}$ (see Table V), the proton resistivity increases dramatically (see Figure 6a), which is reasonable considering that this film thickness corresponds to only $\sim 2$ monolayers of ionomer (based on a PFSA side chain thickness of $\sim 0.5 \mathrm{~nm}^{48}$ ). Thus, as the ionomer film thickness becomes very small, the contribution from oxygen mass transport to the voltage loss becomes very small in contrast to the voltage losses due to poor proton conduction in the cathode (Figure 7e). Thus, a delicate balance between good oxygen mass transport and proton conduction has to be achieved in order to obtain the highest possible performance.

In summary, the here prepared MEAs based on cathodes with $\mathrm{NH}_{\mathrm{x}}$-functionalized carbon support show the highest cell voltage performance at ultra-low Pt loadings reported in the literature. However, even with the evidence for a more homogeneous ionomer distribution achievable with an $\mathrm{NH}_{\mathrm{x}}$-functionalized carbon support, there still remain $\sim 40 \mathrm{mV}$ of unaccounted voltage loss at $2 \mathrm{~A} / \mathrm{cm}^{2}$ geo (see Figure $7 \mathrm{~b})$. In principle, the origin of the unaccounted voltage loss could be due to: i) a not yet optimized MEA design; ii) a deviation from simple Tafel kinetics at low cathode voltages as suggested by Subramanian et al. ${ }^{8}$ and/or, iii) an oxygen mass transport resistance higher than that obtained in the currently used limiting current measurements. While we cannot exclude any of these possibilities, we consider the latter to be most probable, due to the fact that the ratio of heat flux to water generation is higher during limiting current measurements at $0.2 \mathrm{~V}$ than that during polarization curve measurements in $\mathrm{H}_{2} /$ air at $0.5 \mathrm{~V}$, which affects the oxygen mass transport.

\section{Conclusions}

We presented a novel concept for tailoring the ionomer distribution in the catalyst layer. We provide evidence that by functionalizing the surface of a commercially available carbon with $-\mathrm{NH}_{\mathrm{x}}$ groups, the ionomer is homogeneously distributed throughout the catalyst layer, caused by the coulombic attraction between the sulfonate anions of the ionomer and the $\mathrm{NH}_{\mathrm{x}}$ surface groups on the carbon support. This, to our best knowledge, results in the highest $\mathrm{H}_{2}$ /air performance for 
MEAs with ultra-low cathode loadings presented in the literature so far, shown to be due to reduced oxygen mass transport losses through a more homogeneous ionomer film. The presented voltage loss analysis based on proton resistivity and oxygen transport resistance measurements provided detailed insights into the major contributions to the voltage losses in MEAs with low Pt loaded cathodes. Lowering the ionomer/carbon mass ratio from 0.65 to 0.4 , i.e., reducing the effective ionomer film thickness, resulted in reduced oxygen transport resistances and improved fuel cell performance. At I/C ratios of 0.25 , however the performance was limited by poor proton conductivity. Therefore, the key to high performance low Pt loaded cathodes relies on the exquisite balance between good ionomer distribution and low ionomer/carbon ratio with adequate proton conductivity.

\section{Acknowledgments}

This work has been supported by Greenerity GmbH and the German Federal Ministry of Economy (BMWi project support number 03ET2058C) within the HyMotion5 research collaboration. The authors thank Prof. Dr. Sebastian Günther for his help in XPS measurements and Christoph Simon for consulting in mass transport resistance measurements.

\section{References}

1. J. Durst, A. Siebel, C. Simon, F. Hasche, J. Herranz, and H. A. Gasteiger, Energy Environ. Sci., 7, 2255 (2014).

2. O. Groeger, H. A. Gasteiger, and J. P. Suchsland., J. Electrochem. Soc., 162, A2605 (2015).

3. A. Kongkanand and M. F. Mathias, J. Phys. Chem. Lett., 7, 1127 (2016).

4. U. Beuscher, J. Electrochem. Soc., 153, A1788 (2006).

5. D. R. Baker, D. A. Caulk, K. C. Neyerlin, and M. W. Murphy, J. Electrochem. Soc., 156, B991 (2009).

6. Y. Wang and C.-Y. Wang, J. Electrochim. Acta, 50, 1307 (2005)

7. Y. Liu, M. W. Murphy, D. R. Baker, W. Gu, C. Ji, J. Jorne, and H. A. Gasteiger, ECS Trans., 11, 473 (2007).

8. N. P. Subramanian, T. A. Greszler, J. Zhang, W. Gu, and R. Makharia, J. Electrochem. Soc, 159, B531 (2012).

9. A. Z. Weber and A. Kusoglu, J. Mater. Chem. A, 2, 17207 (2014).

10. A. Ohma, T. Mashio, K. Sato, H. Iden, Y. Ono, K. Sakai, K. Akizuki, S. Takaichi, and K. Shinohara, Electrochim. Acta, 56, 10832 (2011).

11. J. P. Owejan, J. E. Owejan, and W. Gu, J. Electrochem. Soc., 160, F824 (2013).

12. Y. Ono, T. Mashio, S. Takaichi, A. Ohma, H. Kanesaka, and K. Shinohara, ECS Trans., 28, 69 (2010).

13. T. A. Greszler, D. Caulk, and P. Sinha, J. Electrochem. Soc., 159, F831 (2012).

14. R. Makharia, N. Subramanian, S. Kumaraguru, T. Greszler, B. Litteer, and Z. Liu, Fuel Cell Seminar and Exposition, Phoenix, AZ, Presentation \# GHT 33-2, 2008.

15. S. Jomori, K. Komatsubara, N. Nonoyama, M. Kato, and T. Yoshida, J. Electrochem. Soc., 160, F1067 (2013).

16. K. Kudo, T. Suzuki, and Y. Morimoto, ECS Trans., 33, 1495 (2010).

17. N. Nonoyama, S. Okazaki, A. Z. Weber, Y. Ikogi, and T. Yoshida, J. Electrochem. Soc., 158, B416 (2011).
18. M. Lopez-Haro, L. Guétaz, T. Printemps, A. Morin, S. Escribano, P. H. Jouneau, P. Bayle-Guillemaud, F. Chandezon, and G. Gebel, Nat. Commun., 5, 5229 (2014).

19. T. Ngo, T. L. Yu, and H. L. Lin, J. Power Sources, 225, 293 (2013)

20. K. Miyazaki, N. Sugimura, K. Kawakita, T. Abe, K. Nishio, H. Nakanishi, M. Matsuoka, and Z. Ogumia , J. Electrochemical Soc., 157, A1153 (2010).

21. L. Sun and T. Okada, J. Membr. Sci., 183, 213 (2001).

22. L. Xin, Y. Kang, F. Yang, A. Uzunoglu, T. Rockward, P. J. Ferreira, R. L. Borup, J. Ilavsky, L. Stanciu, and J. Xie, ECS Conference, Hawai 2016, Abstract 2584.

23. R. J. J. Jansen and H. van Bekkum, Carbon, 32, 1507 (1994).

24. A. Orfanidi, M. K. Daletou, and S. G. Neophytides, J. Appl. Cat. B: Envir., 106, 379 (2011).

25. A. V. Neimark, Y. Lin, P. I. Ravikovitch, and M. Thommes, Carbon, 47, 1617 (2009).

26. G. Y. Gor, M. Thommes, K. A. Cychosz, and A. V. Neimark, Carbon, 50, 1583 (2012).

27. K. Shinozaki, Y. Morimoto, B. S. Pivovar, and S. S. Kocha, J. Power Sources, 325 , 745 (2016).

28. K. J. J. Mayrhofer, D. Strmenik, B. B. Blizanac, V. Stamenkovic, M. Arenz, and N. M. Markovic, Electrochim. Acta, 53, 3181 (2008).

29. C. Simon, F. Hasché, D. Müller, and Hubert A. Gasteiger, ECS Trans., 69, 1293 (2015).

30. W. Gu, D. R. Baker, Y. Liu, and H. A. Gasteiger, in Handbook of Fuel Cells: Advances in Electrocatalysis, Materials, Diagnostics and Durability (editors: W. Vielstich, H. A. Gasteiger, and H. Yokokawa), John Wiley \& Sons, UK Chichester, 631 (2009).

31. S. Kundu, Y. Wang, W. Xia, and M. Muhler, J. Phys. Chem. C, 112, 16869 (2008).

32. G. Zhang, S. Sun, D. Yang, J. Dodelet, and E. Sacher, Carbon, 46, 196 (2008).

33. R. J. J. Jansen and H. van Bekkum, Carbon, 33, 1021 (1995).

34. S. Kundu, W. Xia, W. Busser, M. Becker, D. A. Schmidt, M. Havenith, and M. Muhler, Phys. Chem. Chem. Phys., 12, 4351 (2010).

35. Y. Park, H. Tokiwa, and K. Kakinuma , M. Watanabe and M. Uchida, J. Power Sources, 315, 179 (2016).

36. J. Rouquerol, D. Avnir, C. W. Fairbridge, D. H. Everett, J. M. Haynes, N. Pernicone, J. D. F. Ramsay, K. S. W. Sing, and K. K. Unger. "Recommendations for the characterization of porous solids (Technical Report)." Pure and Appl. Chem., 8, 66 (1994).

37. M. Toupin and D. Be'langer, Langmuir, 24, 1910 (2008).

38. K. C. Neyerlin, W. Gu, J. Jorne, and H. A. Gasteiger, J. Electrochem. Soc., 153, A1955 (2006)

39. H. A. Gasteiger, S. S. Kocha, B. Sompalli, and F. T. Wagner, J. Appl. Catal. B, 56, 9 (2005)

40. F. T. Wagner, S. G. Yan, and P. T. Yu, Handbook of Fuel Cells - Fundamentals, Technology and Applications (eds.: H. Yokokawa, H. A. Gasteiger, and W. Vielstich), John Wiley \& Sons Chichester, 5, 250 (2009).

41. A. Kongkanand, V. Yarlagadda, T. Garrick, T. E. Moylan, and W. Gu, ECS Trans., 75, 25 (2016).

42. Y. Liu, C. Ji, W. Gu, J. Jorne, and H. A. Gasteiger, J. Electrochem. Soc., 158, B614 (2011).

43. Y. Liu, M. W. Murphy, D. R. Baker, W. Gu, C. Ji, J. Jorne, and H. A. Gasteiger, J. Electrochem. Soc., 156, B970 (2009).

44. Y. Liu, C. Ji, W. Gu, D. R. Baker, J. Jorne, and H. A. Gasteiger, J. Electrochem. Soc., 157, B1154 (2010).

45. A. Putz, D. Susac, V. Berejnov, J. Wu, A. P. H. Hitchcock, and J. Stumper, ECS Trans., 75, 3 (2016).

46. K. C. Neyerlin, W. Gu, J. Jorne, Jr. A. Clark, and H. A. Gasteiger, J. Electrochem. Soc., 154, B279 (2007)

47. P. Zihrul, I. Hartung, S. Kirsch, G. Huebner, F. Hasche, and H. A. Gasteiger, J. Electrochem. Soc., 163, F492 (2016).

48. M. Yamaguchi, T. Matsunaga, K. Amemiya, A. Ohira, N. Hasegawa, K. Shinohara, M. Ando, and T. Yoshida, J. Phys. Chem. B, 118, 14922 (2014). 